\author{
Antonio M. Calafiore, $M D^{a}$ \\ Michele Di Mauro, $M D^{b}$ \\ ${ }^{a}$ Department of Adult Cardiac \\ Surgery \\ Prince Sultan Cardiac Center \\ Riyadh, Saudi Arabia \\ ${ }^{b}$ Institute of Cardiovascular Disease \\ University of L'Aquila \\ L'Aquila, Italy
}

\section{References}

1. Frater R. Tricuspid insufficiency. J Thorac Cardiovasc Surg. 2003;125:9-11.

2. Calafiore AM, Iaco' AL, Romeo A, Scandura S, Meduri R, Varone E, et al. Echocardiographicbased treatment of functional tricuspid regurgitation. J Thorac Cardiovasc Surg. 2011;142:308-13.

3. Anwar MA, Geleijnse ML, ten Cate FJ, Meijboom FJ. Assessment of tricuspid valve annulus size, shape and function using real-time three-dimensional echocardiography. Interact CardioVasc Thorac Surg. 2006;5:683-7.
4. Chopra HK, Nanda NC, Fan P, Kapur KK, Goyal R, Daruwalla D, et al. Can two dimensional echocardiography and Doppler flow mapping identify the need for tricuspid repair? JAm Coll Cardiol. 1989;14:1266-74.

5. Sadeghi HM, Kimura BJ, Raisinghani A, Blanchard DG, Mahmud E, Fedullo PF, et al. Does lowering pulmonary arterial pressure eliminate severe functional tricuspid regurgitation? Insights from pulmonary thromboendarterectomy. J Am Coll Cardiol. 2004;44:126-32.

doi:10.1016/j.jtcvs.2011.10.004

\title{
Notice of Correction
}

Re: Chu LM, Osipov RM, Robich MP, Feng J, Oyamada S, Bianchi C, Sellke FW. Is hyperglycemia bad for the heart during acute ischemia? J Thorac Cardiovasc Surg. 2010;140:1345-52.

In the above-mentioned article, acknowledgment of a National Institutes of Health grant was not included. The proper acknowledgment is printed below.

Supported by T32HL007734 (to M.P.R.). 